\title{
Jolanta Drobot
}

Uniwersytet w Białymstoku

joladrobot@gmail.com

ORCID: https://orcid.org/0000-0002-9108-6174

\section{Wygaśnięcie stosunku pracy \\ z przyczyny nieujętej w przepisach prawa - glosa do uchwały Sądu Najwyższego z dnia 1 lutego 2017 r., III PZP $11 / 16$}

http://dx.doi.org/10.12775/SIT.2019.026

\section{Uwagi wstępne}

Przedmiotem rozstrzygnięcia Sądu Najwyższego były trzy zagadnienia prawne:

1. Czy Biuro byłego Prezydenta RP utworzone przez byłego Prezydenta RP jest jednostką organizacyjną, która spełnia kryteria do uznania go za pracodawcę w rozumieniu art. 3 k.p. ${ }^{1}$, czy też pracodawcą osób zatrudnionych w Biurze jest były Prezydent RP?

2. Czy stosunek pracy pracownika Biura byłego Prezydenta RP wygasa wraz ze śmiercią byłego Prezydenta RP?

3. Czy w razie śmierci byłego Prezydenta RP, który utworzył Biuro byłego Prezydenta RP, pracownik tego Biura jest przej-

${ }^{1}$ Ustawa z dnia 26 czerwca 1974 r. Kodeks pracy (tekst jednolity: Dz.U. z 2018 r. poz. 917 ze zm.; dalej: k.p.). 
mowany na zasadach określonych w art. $23^{1} \S 1$ k.p. przez Kancelarię Prezydenta RP?

Sąd Najwyższy w glosowanej uchwale uznał, że pracodawcą wobec pracowników zatrudnionych w Biurze byłego Prezydenta RP jest to Biuro, a ich stosunki pracy wygasają $z$ dniem śmierci byłego Prezydenta RP, co znajduje swoje uzasadnienie w art. $3 \mathrm{w} z w$. $z$ art. $63^{2} \S 1$ i 2 k.p. Zdaniem Sądu Najwyższego, gdy przepisy prawa pracy nie przewidują wygaśnięcia stosunku pracy z powodu trwałego braku osoby uprawnionej do dokonywania czynności w sprawach ze stosunku pracy, konieczne staje się zastosowanie instytucji najbardziej zbliżonej do rozpatrywanej sprawy, czyli wygaśnięcia stosunku pracy $z$ powodu śmierci pracodawcy będącego osobą fizyczną (art. $63^{2}$ k.p.). W efekcie Sąd Najwyższy przyjął, że śmierć osoby fizycznej pełniącej funkcję organu zarządzającego jednostką organizacyjną powoduje wygaśnięcie stosunku pracy. Odnosząc się do trzeciego zagadnienia prawnego, orzekł zaś, iż w sprawie nie doszło do przejścia zakładu pracy w trybie art. $23^{1} \mathrm{k}$.p. W ocenie Sądu Najwyższego o przejściu zakładu pracy można mówić wtedy, gdy wskutek określonych zdarzeń prawnych zakład pracy zostaje przejęty przez inny podmiot, który kontynuuje przejmowaną działalność. Natomiast w analizowanej sprawie zadania związane z obsługą działalności byłego Prezydenta RP wykluczają kontynuowanie przez inny podmiot działalności tego samego rodzaju lub zbliżonej ${ }^{2}$.

Glosowana uchwała dotyczy jednej z podstawowych instytucji prawa pracy, jaką jest wygaśnięcie stosunku pracy. Pogląd Sądu Najwyższego, wyrażony w orzeczeniu z dnia 1 lutego 2017 r., zasługuje na szersze omówienie, gdyż dotyczy spornego w praktyce problemu wygaśnięcia stosunku pracy z przyczyny niewyrażonej $\mathrm{w}$ przepisie prawa. Zapadłe rozstrzygnięcie może budzić uzasadnione wątpliwości dotyczące podstawy orzeczenia przez Sąd Najwyższy o wygaśnięciu stosunku pracy. Związane $z$ tą problematyką niejasności pojawiają się także w kontekście innych przypadków wygaśnięcia stosunku pracy nieuregulowanych w przepisach prawa,

${ }^{2}$ III PZP 11/16, Lex nr 2198981. 
jak np. wygaśnięcie stosunku pracy z powodu ubezwłasnowolnienia całkowitego pracownika. Należy ocenić, czy orzeczenie o wygaśnięciu stosunku pracy $z$ tej przyczyny jest zgodne $z$ funkcją ochronną prawa pracy. Chodzi o ustalenie, czy w wyniku rozstrzygnięcia Sądu Najwyższego o wygaśnięciu stosunku pracy nie doszło do ograniczenia bądź nawet pozbawienia pracownika ochrony jego praw.

\section{Pracodawca jako jednostka organizacyjna nieposiadająca osobowości prawnej}

Trafnie zostało przez Sąd Najwyższy ocenione, że zgodnie $z$ art. 3 k.p. Biuro byłego Prezydenta RP, jako jednostka organizacyjna nieposiadająca osobowości prawnej, było pracodawcą pracownicy tego Biura. Stosownie do tego przepisu, pracodawcą jest jednostka organizacyjna, choćby nie posiadała osobowości prawnej, a także osoba fizyczna, jeżeli zatrudniają one pracowników. $Z$ brzmienia kodeksowej definicji pojęcia pracodawcy wynika, że pracodawcą może być osoba fizyczna, jak i jednostka organizacyjna - posiadająca osobowość prawną bądź jej pozbawiona. Wobec jednostek organizacyjnych, które są pozbawione osobowości prawnej, formułuje się wymagania, które należy spełnić, aby dany podmiot mógł być pracodawcą. Chodzi o uregulowaną strukturę pozwalającą na kierowanie swoimi sprawami w stosunkach wewnętrznych oraz majątek wyodrębniony $z$ majątku członków bądź założycieli ${ }^{3}$. Oprócz tego Teresa Liszcz wskazuje, że jednostka organizacyjna może być pracodawcą, jeśli jest dopuszczona przez prawo ${ }^{4}$.

Zgodnie z ustaleniami Sądu Najwyższego, Biuro Byłego Prezydenta RP zostało wyodrębnione organizacyjnie i finansowo, a także działało na podstawie przepisów prawa ${ }^{5}$. Otrzymywało środki finan-

\footnotetext{
${ }^{3}$ K.W. Baran, Komentarz do Kodeksu pracy, Warszawa 2018, s. 48.

4 T. Liszcz, Prawo pracy, Warszawa 2016, s. 122.

${ }^{5}$ Sąd Najwyższy podał, że Biuro byłego Prezydenta RP zostało utworzone w oparciu o Zarządzenie nr 14 Szefa Kancelarii Prezydenta Rzeczypospolitej Polskiej z dnia 17 września 1996 r. (niepublikowane, ze zmianami), wydanego na podstawie $\S 2$ ust. 3 statutu Kancelarii Prezydenta, stanowiącego załącznik
} 
sowe na funkcjonowanie, samodzielnie wypłacało wynagrodzenie za pracę oraz opłacało składki na ubezpieczenie społeczne. Został mu nadany numer REGON, co również świadczy o wystarczającym wyodrębnieniu go $\mathrm{w}$ obrocie prawnym jako określonej jednostki organizacyjnej. Biuro byłego Prezydenta RP miało możliwość bycia stroną stosunków pracy oraz stosunków zobowiązaniowych. W efekcie samodzielnie prowadziło swoje sprawy i realizowało zadania związane $z$ działalnością byłego Prezydenta RP w sferze publicznej. Przy tym Biuro nie zostało utworzone przez byłego Prezydenta RP $\mathrm{w}$ celach prywatnych czy też $\mathrm{w}$ celu ewentualnego prowadzenia przez niego działalności gospodarczej. Wówczas mogłoby to uzasadniać założenie, że sam Prezydent RP, jako osoba fizyczna bądź osoba fizyczna prowadząca działalność gospodarczą, jest pracodawcą zatrudnianych przez siebie pracowników.

\section{Katalog przyczyn wygaśnięcia stosunku pracy}

Zasadniczym problemem w analizowanej sprawie jest możliwość zakwalifikowania zdarzenia, jakim jest śmierć osoby fizycznej pełniącej funkcję organu zarządzającego jednostką będącą pracodawcą, jako przyczyny wygaśnięcia stosunku pracy.

Zgodnie $z$ art. 63 k.p. umowa o pracę wygasa w przypadkach określonych w kodeksie oraz w przepisach szczególnych. Normy kodeksowe regulują wygaśnięcie stosunku pracy z powodu śmierci pracownika (art. $63^{1}$ k.p.), z powodu śmierci pracodawcy (art. $63^{2}$ k.p.), w związku $z$ upływem trzymiesięcznej nieobecności pracownika w pracy $z$ powodu tymczasowego aresztowania (art. 66 k.p.) oraz w sytuacji, gdy pracownik $z$ wyboru pozostaje na urlopie bezpłatnym i nie korzysta $z$ czasowego prawa powrotu do pracy u poprzedniego

do Zarządzenia nr 2/96 Prezydenta Rzeczypospolitej Polskiej z dnia 26 stycznia 1996 r. w sprawie nadania statutu Kancelarii Prezydenta Rzeczypospolitej Polskiej oraz w związku z wyżej powołanym art. 4 i 9 ustawy z dnia 30 maja 1996 r. o uposażeniu byłego Prezydenta Rzeczypospolitej Polskiej. 
pracodawcy (art. 74 k.p.). Do przyczyn wygaśnięcia stosunku pracy uregulowanych w przepisach szczególnych należą m.in. wygaśnięcie stosunku pracy kuratora zawodowego w wypadku zrzeczenia się przez niego obywatelstwa polskiego (art. 26 ust. 2 Ustawy $z$ dnia 27 lipca 2001 r. o kuratorach sądowych) ${ }^{6}$ czy też wygaśnięcie stosunku pracy opartego na spółdzielczej umowie o pracę w związku z ustaniem członkostwa w spółdzielni (art. 186 § 1 Ustawy z dnia 16 września 1982 r. Prawo spółdzielcze) ${ }^{7}$.

Kwestia przyczyn wygaśnięcia stosunku pracy jest sporna ${ }^{8}$. Można wyróżnić dwa stanowiska doktryny prawniczej i orzecznictwa w zakresie charakteru katalogu zdarzeń powodujących wygaśnięcie stosunku pracy.

Pierwsza koncepcja opiera się na założeniu, że katalog zdarzeń skutkujących wygaśnięciem stosunku pracy ma charakter zamknięty. Wskazuje się, że katalog ten może być określony tylko odpowiednimi przepisami, co jednoznacznie wynika z treści art. 63 k.p. Niedopuszczalne jest więc stosowanie analogii ani wykładni rozszerzającej. Innymi słowy, sankcji wygaśnięcia stosunku pracy nie można w żadnym razie domyślać się lub wywodzić w drodze wykładni per analogiam ${ }^{9}$. Podkreśla się, że zdarzenia powodujące wygaśnięcie umowy o pracę są określone w prawie pracy wyczerpująco ${ }^{10}$.

${ }^{6}$ Tekst jednolity: Dz.U. z 2018 r. poz. 1014 ze zm.

7 Tekst jednolity: Dz.U. z 2018 r. poz. 1285 ze zm.

${ }^{8}$ M. Gersdorf, Komentarz do art. 63 k.p., w: M. Gersdorf, K. Rączka, M. Raczkowski, Kodeks pracy. Komentarz, Warszawa 2012, s. 431.

${ }_{9}$ Wyrok SN z dnia 11 grudnia 2007 r., I PK 160/07, Lex nr 478452; podobne stanowisko wyraził również SN w wyroku z dnia 4 października 2006 r., II PK 14/06, Lex nr 309367.

${ }^{10}$ K. W. Baran, Komentarz, s. 484; L. Florek, Komentarz do Kodeksu pracy, Warszawa 2017, s. 414; A. Malinowski, Nawiazywanie i rozwiazywanie stosunku pracy. Komentarz praktyczny, Warszawa 2015, s. 135; P. Wąż, Komentarz do art. 63, w: Komentarz do Kodeksu pracy, red. K. Walczak, Beck Online 2020; idem, Następstwa prawne śmierci strony stosunku pracy, „Monitor Prawa Pracy"2008, nr 4, s. 181; W. Muszalski, Komentarz do Kodeksu pracy, Warszawa 2017, s. 414; M.T. Romer, Komentarz do Kodeksu pracy, Warszawa 2012 , s. 482; K. Jaśkowski, Komentarz do art. 63, w: K. Jaśkowski, E. Maniewska, Kodeks pracy. Komentarz. Ustawy towarzyszace wraz $z$ orzecznictwem. Europejskie prawo pracy z orzecznictwem, t. I, Warszawa 2016, s. 391; Z. Kubot, 
Pogląd ten podziela również część orzecznictwa. Sąd Apelacyjny w Białymstoku w wyroku z dnia 9 marca 2016 r. orzekł, że wygaśnięcie umowy o pracę nie może być przyjmowane w sposób dowolny lub domniemany, skoro art. 63 k.p. wskazuje, że umowa o pracę wygasa w przypadkach określonych w kodeksie oraz w przepisach szczególnych $^{11}$. Podobnie wypowiedział się Sąd Apelacyjny w Łodzi w wyroku z dnia 22 lipca 2015 r. Zajął on stanowisko, że zarówno kodeks pracy, jak i przepisy szczególne zawierają zamknięty katalog przyczyn powodujących wygaśnięcie stosunku pracy, wśród których nie ma regulacji wskazującej, iż stosunek pracy wygasa na skutek zaprzestania prowadzenia działalności gospodarczej przez podmiot zatrudniający pracownika ${ }^{12}$.

Zwolennicy przeciwnego stanowiska, opartego na koncepcji otwartego katalogu przyczyn wygaśnięcia stosunku pracy, odwołują się do wykładni funkcjonalnej art. 63 k.p., odnoszącej się do istoty stosunku pracy. Podkreśla się, że w dalszym ciągu występują przypadki, co do których ocena z punktu widzenia bytu stosunku pracy nie była wcześniej i obecnie nie jest przesądzona ${ }^{13}$. W tym kontekście wyrażana jest wątpliwość, czy istnieje możliwość stworzenia jednego, pełnego katalogu przyczyn wygaśnięcia stosunku pracy. Proponuje się rezygnację z zamkniętego przez ustawę katalogu zda-

Wygaśnięcie stosunku pracy, w: Prawo pracy. Zarys wykładu, red. H. Szurgacz, Warszawa 2016, s. 155; W. Witoszko, Przyczyny wygaśnięcia stosunku pracy $w$ powszechnym i szczególnym prawie pracy, w: Powszechne a szczególne prawo pracy, red. L. Florek, Warszawa 2016, s. 172; D. Klucz, Wygaśnięcie umowy o pracę a inne tryby ustania zatrudnienia, „Monitor Prawa Pracy” 2007, nr 2, s. 73, 77; B. Cudowski, O niektórych kontrowersjach $w$ sprawie ustalenia sposobu ustania stosunku pracy, „Praca i Zabezpieczenie Społeczne” 2010, nr 12, s. 6; A. Rycak, Wygaśnięcie umowy o pracę, w: Prawo pracy, red. J. Stelina, Warszawa 2018, s. 228-229; E. Wichrowska-Janikowska, Nawiązywanie i rozwiązywanie umów o pracę, Toruń 1996, s. 85.

${ }^{11}$ III AUa 735/15, Lex nr 2065051.

12 III AUa 572/14, Lex nr 1927598. O tym, że umowa o pracę może wygasnąć w wypadkach określonych wyłącznie w ustawie, orzeczono również w wyroku SN z dnia 8 listopada 2012 r., II UK 84/12, Lex nr 1380816.

${ }^{13}$ J. Stelina, Ewolucja kodeksowej regulacji wygaśnięcia stosunku pracy, „Studia Iuridica Lublinensia” 2015, vol. XXIV, s. 231. 
rzeń powodujących wygaśnięcie stosunku pracy poprzez skreślenie art. 63 k.p. Zdaniem zwolenników tej koncepcji dotychczasowa praktyka wskazuje, że przepis ten nigdy nie był zbyt rygorystycznie przestrzegany. Obecnie po ugruntowaniu koncepcji wygaśnięcia stosunku pracy skreślenie art. 63 k.p. nie powodowałoby żadnych negatywnych konsekwencji ${ }^{14}$.

W analizowanej uchwale $z$ dnia 1 lutego 2017 r. Sąd Najwyższy stwierdził, że w judykaturze przyjmowało się i przyjmuje, iż obowiązujące przepisy, a w szczególności Kodeks pracy, nie regulują wprost wszystkich przypadków wygaśnięcia stosunku pracy jako podstawy jego ustania. O kwalifikacji sposobu (rozwiązania lub wygaśnięcia) decydują okoliczności faktyczne sprawy. Możliwe jest więc przyjęcie, że w pewnych nietypowych i nieuregulowanych wprost w przepisach okolicznościach doszło do wygaśnięcia stosunku pracy ${ }^{15}$. Sąd ten w swoich rozważaniach odwołał się do wyroku Sądu Najwyższego $z$ dnia 7 kwietnia 2010 r. ${ }^{16}$ oraz do wyroku Sądu Najwyższego $z$ dnia 9 lutego 2012 r. ${ }^{17} \mathrm{~W}$ orzeczeniach tych sformułowano tezę, że stosunek pracy wspólnika spółki $z$ ograniczoną odpowiedzialnością będącego prezesem jej jednoosobowego zarządu wygasa $z$ chwilą nabycia przez niego wszystkich udziałów w spółce. Powyższy pogląd podzielił doktrynę prawa pracy. $Z$ jednej strony wyrażono stanowisko aprobujące ustalenia Sądu Najwyższego ${ }^{18}, \mathrm{z}$ drugiej zaś pogląd ten został poddany krytyce. W ocenie Bogusława Cudowskiego $z$ uwagi na kategoryczne brzmienie art. 63 k.p. trzeba uznać, iż nie ma podstaw do przyjęcia, aby w tym przypadku doszło do wygaśnięcia stosunku pracy. Właściwe byłoby rozstrzygnięcie, że nabycie

${ }^{14}$ Ibidem, s. 233-234.

${ }^{15}$ III PZP $11 / 16$.

${ }^{16}$ II UK 357/09, Lex nr 987623.

17 I UK 260/11, Lex nr 1169835; również wyrok SA w Gdańsku z dnia 17 stycznia 2018 r., III AUa 939/17, Lex nr 2463478; wyrok SO w Bydgoszczy z dnia 28 marca 2017 r., VI U 1082/16, Lex nr 2318383; wyrok SO w Siedlcach z dnia 2 czerwca 2016 r., IV U 313/14, Lex nr 2081783; wyrok SA w Gdańsku z dnia 24 października 2012 r., III AUa 687/12, Lex nr 1236247.

18 M. Giaro, Glosa do wyroku Sądu Najwyższego z 7 kwietnia 2010 r. (II UK 357/09) $w$ sprawie pracowniczego statusu członka zarządu, „Praca i Zabezpieczenie Społeczne” 2011, nr 10, s. 38-40. 
wszystkich udziałów przez prezesa jednoosobowego zarządu spółki z ograniczoną odpowiedzialnością prowadzi do rozwiązania umowy o pracę za dorozumianym porozumieniem stron ${ }^{19}$.

Według zwolenników koncepcji otwartego katalogu przyczyn wygaśnięcia stosunku pracy innym przykładem zdarzenia powodującego wygaśnięcie tego stosunku jest likwidacja zakładu pracy ${ }^{20}$. Pogląd ten został zanegowany przez Sąd Najwyższy w wyroku z dnia 5 września 2001 r., w którym orzeczono, że likwidacja pracodawcy nie jest zdarzeniem powodującym wygaśnięcie umowy o pracę ${ }^{21}$.

W doktrynie prawniczej występują również stanowiska, iż ubezwłasnowolnienie całkowite pracownika powoduje wygaśnięcie stosunku pracy. Wskazuje się, że pracownik, tracąc zdolność do czynności prawnych, na gruncie prawa pracy traci tzw. zdolność pracowniczą. $Z$ tego powodu nie jest możliwe dalsze wykonywanie przez niego pracy. Fakt utraty zdolności pracowniczej uniemożliwia nakładanie na pracownika przez pracodawcę obowiązków i oczekiwanie ich świadomego wypełnienia i odpowiadania za ich wykonanie zgodnie ze standardami określonymi w zakładzie pracy. Wygaśnięcie stosunku pracy z tej przyczyny miałoby nastąpić z dniem uprawomocnienia się postanowienia sądu w przedmiocie ubezwłasnowolnienia osoby fizycznej ${ }^{22}$.

\section{Wygaśnięcie stosunku pracy z powodu śmierci Prezydenta RP prowadzącego Biuro byłego Prezydenta RP}

W uchwale $z$ dnia 1 lutego 2017 r. Sąd Najwyższy uznał, że obecnie obowiązujące przepisy prawa w sposób niewyczerpujący regulują

19 B. Cudowski, O niektórych kontrowersjach, s. 6; Z. Kubot, Status ordynatora, „Prawo i Medycyna” 2001, nr 10, s. 75.

20 J. Stelina, Ewolucja, s. 232-233.

${ }^{21}$ I PKN 830/00, Lex nr 49684.

22 M. Zbucka, Skutki prawne śmierci pracodawcy, Lex Online 2018; J. Stelina, Prawo pracy, s. 124. 
przypadki wygaśnięcia stosunku pracy. Zdaniem sądu w sprawie zachodziła konieczność sięgnięcia do przepisów prawa regulujących przypadki najbardziej zbliżone do rozstrzyganego problemu. $\mathrm{W}$ efekcie Sąd Najwyższy na podstawie art. $3 \mathrm{w}$ związku $\mathrm{z}$ art. $63^{2}$ $\S 1$ i 2 k.p. orzekł, iż stosunek pracy pracownicy wygasł $z$ dniem śmierci Prezydenta RP, tj. osoby fizycznej sprawującej funkcję organu zarządzającego jednostką organizacyjną będącą pracodawcą. Moim zdaniem $z$ tym stanowiskiem Sądu Najwyższego nie sposób się zgodzić.

Ustawodawca w prawie polskim szczegółowo określił katalog przyczyn wygaśnięcia stosunku pracy. Nie można zatem przyjmować, że śmierć osoby fizycznej pełniącej funkcję organu zarządzającego jednostką organizacyjną powoduje wygaśnięcie stosunku pracy. Sytuacja ta nie ma oparcia w żadnym przepisie prawa regulującego instytucję wygaśnięcia stosunku pracy. Moim zdaniem z treści art. 63 k.p. wynika jednoznacznie, że przyczyny wygaśnięcia stosunku pracy reguluje wyłącznie Kodeks pracy oraz przepisy szczególne. Przy takim brzmieniu przepisu nie wydaje się uprawnione przyjęcie, że inne przypadki, niewyrażone w przepisie rangi ustawowej, powodują wygaśnięcie stosunku pracy. Innymi słowy: z przepisu tego wynika, że póki nie nastąpi żadne ze zdarzeń powodujących wygaśnięcie stosunku pracy, stosunek ten nadal trwa. Nie ma również podstaw do założenia, aby łącząca strony umowa o pracę wygasła, skoro nie zaistniały żadne okoliczności warunkujące uznanie wygaśnięcia tej umowy ${ }^{23}$. Mimo śmierci byłego Prezydenta RP, dla którego prowadzone było Biuro, nie przestało ono istnieć. Powstały wyłącznie podstawy do jego likwidacji. W sferze zatrudnienia pracownicy zmienił się jedynie zakres obowiązków, do których od tej chwili należało podejmowanie czynności zmierzających do likwidacji jednostki organizacyjnej będącej jej pracodawcą. W analizowanej przez Sąd Najwyższy sprawie mimo śmierci osoby fizycznej pełniącej funkcję organu zarządzającego Biurem jako pracodawcą nie doszło do utraty bytu prawnego przez którąkolwiek

${ }^{23}$ Wyrok SR we Wrocławiu $z$ dnia 7 lipca 2016 r., IV U 195/16, Lex nr 2107627. 
ze stron stosunku pracy. Wobec powyższego nie można przyjąć, że stosunek pracy wygasł wraz ze śmiercią osoby fizycznej pełniącej funkcję organu zarządzającego, ponieważ nie spowodowało to w żaden sposób zakończenia istnienia Biura jako pracodawcy.

Co więcej, stosownie do art. 3 k.p., pracodawcą jest jednostka organizacyjna, choćby nie posiadała osobowości prawnej, a także osoba fizyczna, jeżeli zatrudniają one pracowników. Przepis ten wskazuje wprost na podmioty prawa, które mogą zatrudniać pracowników. Definicja pracodawcy nie została rozszerzona na osoby fizyczne pełniące funkcję organów zarządzających jednostką organizacyjną będącą pracodawcą, gdyż de facto nie pełnią one takiej funkcji, a jedynie dokonują czynności prawnych w imieniu i na rzecz tej jednostki. Powyższe znajduje swoje uzasadnienie również w art. $3^{1} \S 1$ k.p. stanowiącym, że za pracodawcę będącego jednostką organizacyjną czynności w sprawach z zakresu prawa pracy dokonuje osoba lub organ zarządzający tą jednostką albo inna wyznaczona do tego osoba. Przepis ten odwołuje się do statusu pracodawcy w przypadku jednostki organizacyjnej, ale w żadnej mierze nie rozszerza pojęcia pracodawcy na osoby zarządzające tą jednostką. Wskazuje on jedynie na kompetencje do podejmowania czynności w imieniu i na rzecz jednostki organizacyjnej będącej pracodawcą.

Zgodnie z ustaleniami sądu rejonowego, jedyna pracownica Biura byłego Prezydenta RP po jego śmierci zajęła się likwidacją Biura. W doktrynie prawa zwraca się uwagę na problem istnienia stosunku pracy po zakończeniu procesu likwidacji, jeśli do tego czasu stosunek pracy nie został rozwiązany przez pracodawcę. Podnosi się, że zdarzają się przypadki, gdy formalne wykreślenie $z$ rejestru jednostki organizacyjnej nie było poprzedzone wcześniejszym rozwiązaniem wszystkich umów o pracę (np. z pracownikiem przebywającym na długotrwałym urlopie bezpłatnym). Z pewnością po likwidacji pracodawcy nie jest możliwe, by w dalszym ciągu trwał jakikolwiek stosunek pracy, w którym ten pracodawca pozostawał ${ }^{24}$. Niemniej jednak słusznie się wskazuje, że ogłoszenie upadłości,

${ }^{24}$ J. Stelina, Ewolucja, s. 233. Zdaniem autora z chwilą likwidacji pracodawcy stosunek pracy wygasa. 
jak również wszczęcie likwidacji pracodawcy nie prowadzi do automatycznego ustania stosunku pracy. Stosunki pracy nie wygasają z dniem ogłoszenia upadłości lub likwidacji podmiotu zatrudniającego. W celu zakończenia ich trwania konieczne jest złożenie oświadczenia woli w przedmiocie rozwiązania stosunku pracy ${ }^{25}$. $\mathrm{W}$ piśmiennictwie ujęto sytuacje, w których stosunek pracy $\mathrm{z}$ określonymi pracownikami nie został rozwiązany pomimo zakończenia postępowania likwidacyjnego. Uzasadniałoby to ocenę, że $z$ chwilą zakończenia likwidacji pracodawcy doszło do rozwiązania stosunku pracy za dorozumianym porozumieniem stron (art. 60 k.c. ${ }^{26} \mathrm{~W}$ zw. $\mathrm{z}$ art. 300 k.p.). Trudno jest bowiem przyjąć, że stosunek pracy istnieje pomimo utraty bytu prawnego jednostki organizacyjnej będącej pracodawcą w wyniku zakończenia jej likwidacji ${ }^{27}$. Również orzecznictwo dopuszcza możliwość rozwiązania stosunku pracy $\mathrm{w}$ sposób dorozumiany $\mathrm{z}$ chwilą zlikwidowania pracodawcy. W wyroku Sądu Najwyższego z dnia 17 lutego 2015 r. trafnie zostało wskazane, że wypowiedzenie umowy o pracę może być wyrażone w sposób dorozumiany przez faktyczne zaprzestanie wykonywania działalności gospodarczej przez pracodawcę. Dorozumiane wypowiedzenie umowy o pracę wywołuje taki sam skutek jak oświadczenie złożone w sposób wyraźny - umowę o pracę rozwiązuje się nie $z$ dniem złożenia dorozumianego oświadczenia woli (jego dotarcia do adresata), ale $z$ upływem okresu wypowiedzenia ${ }^{28}$. Moim zdaniem taką konstrukcję prawną winien również przyjąc Sąd Najwyższy w głosowanej uchwale.

25 A. Tomanek, Stosunki pracy $w$ razie likwidacji $i$ upadłości pracodawcy, Warszawa 2012, s. 197-198.

${ }^{26}$ Ustawa $z$ dnia 23 kwietnia 1964 r. Kodeks cywilny (tekst jednolity: Dz.U. z 2018 r. poz. 1025 ze zm.; dalej: k.c.).

27 B. Cudowski, O niektórych kontrowersjach, s. 5; A. Tomanek, Stosunki pracy, s. 200-201.

28 I UK 227/14, Lex nr 1653741; również orzeczenia przywołane przez Sąd Najwyższy w tym wyroku, tj. wyrok SN z dnia 5 marca 1999 r., I PKN 627/98, Lex nr 38952; wyrok SN z dnia 19 marca 2002 r., I PKN 209/01, Lex nr 54669; czy też przykładowo wyrok SN z dnia 8 listopada 2012 r., II UK 84/12, Lex nr 1380816; wyrok SN z dnia 26 listopada 2002 r., I PKN 659/00, Lex nr 577449. 


\section{Przejście Biura byłego Prezydenta RP na nowego pracodawcę w postaci Kancelarii Prezydenta RP w trybie art. $23^{1}$ k.p.}

Sąd Najwyższy w omawianej uchwale $z$ dnia 1 lutego 2017 r. odmówił odpowiedzi na trzecie zagadnienie prawne przedstawione przez sąd okręgowy. Zagadnienie to odnosiło się do ustalenia, czy w przypadku śmierci byłego Prezydenta RP, dla którego prowadzone było Biuro byłego Prezydenta RP, pracownik Biura przejmowany jest na zasadach wyrażonych w art. $23^{1} \S 1$ k.p. przez Kancelarię Prezydenta RP.

Słusznie Sąd Najwyższy uznał, że w rozpoznawanej sprawie nie mogło dojść do przejścia zakładu pracy w trybie art. $23^{1} \mathrm{k}$.p. Instytucja przejścia zakładu pracy nierozerwalnie wiąże się z prowadzeniem dotychczasowych działalności przejmowanego pracodawcy, co w omawianej sprawie nie miało racji bytu. Działalność Biura jako zakładu pracy sprowadzała się wyłącznie do obsługi działalności byłego Prezydenta RP. Nie była to działalność gospodarcza, lecz dotycząca aktywności byłego Prezydenta RP w sferze publicznej. Innymi słowy: wykonywanie przez Biuro tych zadań było ściśle związane $z$ osobą byłego Prezydenta RP i zajmowanym niegdyśs urzędem. $Z$ ugruntowanej linii orzeczniczej, do której odniósł się Sąd Najwyższy, wynika, że w przypadku pracodawcy realizującego cele publiczne o przejściu zakładu pracy decyduje przede wszystkim przejęcie jego zadań ${ }^{29}$. Ocena, że doszło do przejścia zakładu pracy na nowego pracodawcę, zależy od ustalenia, czy przejął on w faktycznie władanie zadania lub część zadań stanowiących podstawę funkcjonowania placówki zatrudnienia ${ }^{30}$. W omawianej sprawie do przejęcia zadań Biura byłego Prezydenta RP nie doszło, gdyż

${ }^{29}$ Wyrok SN z dnia 10 października 2003 r., I PK 456/2002, Lex nr 122184; uchwała SN z dnia 28 marca 2013 r., III PZP 1/13, Lex 1294241 i przywołane w jej uzasadnieniu orzecznictwo Trybunału Sprawiedliwości Unii Europejskiej oraz Sądu Najwyższego.

${ }^{30}$ Wyrok SN z dnia 20 października 2009 r., I PK 96/09, Lex 785132. 
z chwilą śmierci byłego Prezydenta RP odpadła podstawa do dalszej realizacji tych zadań. Jednocześnie rozpoczął się proces likwidacji Biura, co świadczy o zakończeniu dotychczasowej działalności tej jednostki organizacyjnej.

\section{Podsumowanie}

Należy podzielić ustalenia Sądu Najwyższego odnoszące się do uznania, że pracodawcą wobec pracowników zatrudnionych w Biurze byłego Prezydenta RP było to Biuro. Trafnie również Sąd Najwyższy orzekł, że w analizowanej sprawie nie mogło dojść do przejścia zakładu pracy w trybie art. $23^{1} \mathrm{k}$.p. Jednakże nie zasługuje na aprobatę jego pogląd, iż stosunek pracy pracownicy Biura wygasł $\mathrm{z}$ dniem śmierci byłego Prezydenta RP, pełniącego funkcję organu zarządzającego jednostką organizacyjną będącą pracodawcą.

Uważam, że obowiązujące przepisy prawa pracy dotyczące instytucji wygaśnięcia stosunku pracy stanowią wyczerpujący katalog zdarzeń powodujących ustanie tego stosunku prawnego. Należy zatem zgodzić się ze zwolennikami koncepcji zamkniętego katalogu przyczyn wygaśnięcia stosunku pracy, iż wygaśnięcia stosunku pracy nie można domniemywać ani wyprowadzać w drodze analogii $z$ innych przepisów prawa. $W$ przypadku zdarzeń prowadzących do ustania stosunku pracy, które nie zostały poprzedzone procedurą jego rozwiązania, zasadne jest przyjęcie rozwiązania stosunku pracy za dorozumianym porozumieniem stron. Sposób ustania stosunku pracy ma bowiem zasadnicze znaczenie dla pracownika. Łatwość uznania, że doszło do wygaśnięcia stosunku pracy, może powodować nadużycia $\mathrm{w}$ doprowadzaniu do zakończenia trwania tego stosunku. Wymaga się zatem właściwego stosowania przepisów, aby nie ograniczać funkcji ochronnej przepisów prawa pracy ${ }^{31}$. Oparcie się na koncepcji wygaśnięcia stosunku pracy może powodować niepewność prawną, jako że nie wymaga się złożenia oświadczenia woli nakierowanego na ustanie stosunku pracy ${ }^{32}$. Co więcej, przy

${ }^{31}$ M. Zbucka, Skutki prawne.

32 A. Tomanek, Stosunki pracy, s. 201. 
wystąpieniu wygaśnięcia stosunku pracy pracodawca nie ma także obowiązku podawania przyczyny jego ustania (art. 30 § 4 k.p.) czy też konsultowania zakończenia stosunku pracy $z$ tej przyczyny z zakładową organizacją związkową (art. 38 k.p.). Ustanie stosunku pracy w wyniku jego wygaśnięcia może nastąpić wobec pracownika, któremu brakuje nie więcej niż 4 lata do osiągnięcia wieku emerytalnego (art. 39 k.p.), jak również w trakcie usprawiedliwionej nieobecności w pracownika w pracy (art. 41 k.p.). Ochrona stosunku pracy nie występuje w przypadku wygaśnięcia stosunku pracy łączącego pracodawcę i pracownicę będącą w ciąży. Przyjęcie, że stosunek pracy ustał wobec jego wygaśnięcia pozbawia również pracownika prawa do odprawy pieniężnej. Ponadto może to decydować o podleganiu ubezpieczeniom społecznym czy też prawie powrotu na poprzednio zajmowane stanowisko. Pracownikowi nie przysługuje także żądanie ustalenia istnienia stosunku pracy czy zapłaty wynagrodzenia za gotowość do świadczenia pracy ${ }^{33}$. W konsekwencji instytucja wygaśnięcia stosunku pracy winna być stosowania $z$ dużą rozwagą i tylko, gdy dane zdarzenie ma oparcie w przepisach prawa stanowiących o wygaśnięciu stosunku pracy.

\section{STRESZCZENIE}

Wygaśnięcie stosunku pracy z przyczyny nieujętej w przepisach prawa - glosa do uchwały Sądu Najwyższego Z dnia 1 lutego 2017 r., III PZP 11/16

Celem niniejszego opracowania jest próba oceny zasadności rozstrzygnięcia podjętego przez Sąd Najwyższy w uchwale $z$ dnia 1 lutego 2017 r., III PZP 11/16. Sąd Najwyższy uznał, że pracodawcą wobec pracowników zatrudnionych w Biurze byłego Prezydenta RP jest to Biuro, a ich stosunki pracy wygasają $z$ dniem śmierci byłego Prezydenta RP, co znajduje swoje uzasadnienie $\mathrm{w}$ art. $3 \mathrm{w}$ związku $\mathrm{z}$ art. $63^{2} \S 1$ i 2 k.p. Pogląd ten może budzić kontrowersje $z$ powodu uznania przez Sąd wygaśnięcia stosunku pracy $\mathrm{z}$ przyczyny nieuregulowanej $\mathrm{w}$ przepisie prawa.

${ }^{33}$ B. Cudowski, O niektórych kontrowersjach, s. 5, 7. 
Słowa kluczowe: wygaśnięcie stosunku pracy; pracodawca; pracownik; katalog przyczyn wygaśnięcia stosunku pracy; przejście zakładu pracy

\section{SUMMARY}

Expiry of an employment relationship for a reason not regulated by law - a gloss to the resolution of the Supreme Court of February 1, 2017, III PZP 11/16

The purpose of this study is an attempt to assess the legitimacy of the decision taken by the Supreme Court in the resolution of February 1, 2017, III PZP 11/16. The Supreme Court decided that the employer of employees employed in the Office of the ex-President of the Republic of Poland is the Office, and their employment relationships expire on the day of the death of the ex-President of the Republic of Poland, which is justified by art. 3 in connection with art. $63^{2} \S 1$ and 2 Labor Code. This view may be controversial in connection with the Court's recognition of the termination of an employment relationship for a reason not regulated by the law.

Keywords: expiry of the employment relationship; employer; employee; catalog of reasons for termination of employment; transition of the workplace

\section{BIBLIOGRAFIA}

Baran K. W., Komentarz do Kodeksu pracy, Warszawa 2018.

Cudowski B., O niektórych kontrowersjach $w$ sprawie ustalenia sposobu ustania stosunku pracy, „Prawo i Zabezpieczenie Społeczne” 2010, nr 12.

Florek L., Komentarz do Kodeksu pracy, Warszawa 2017.

Florek L., Powszechne a szczególne prawo pracy, Warszawa 2016.

Gersdorf M., Rączka K., Raczkowski M., Kodeks pracy. Komentarz, Warszawa 2012.

Giaro M., Glosa do wyroku Sądu Najwyższego z 7 kwietnia 2010 r. (II UK 357/09) w sprawie pracowniczego statusu członka zarządu, „Prawo i Zabezpieczenie Społeczne” 2011, nr 10.

Jaśkowski K., Maniewska E., Kodeks pracy. Komentarz. Ustawy towarzyszace wraz $z$ orzecznictwem. Europejskie prawo pracy $z$ orzecznictwem, t. I, Warszawa 2016.

Klucz D., Wygaśnięcie umowy o pracę a inne tryby ustania zatrudnienia, „Monitor Prawniczy” 2007, nr 2. 
Kubot Z., Status ordynatora, „Prawo i Medycyna” 2001, nr 10.

Liszcz T., Prawo pracy, Warszawa 2016.

Malinowski A., Nawiąywanie i rozwiazywanie stosunku pracy. Komentarz praktyczny, Warszawa 2015.

Muszalski W., Komentarz do Kodeksu pracy, Warszawa 2017.

Romer M.T., Komentarz do Kodeksu pracy, Warszawa 2012.

Stelina J., Ewolucja kodeksowej regulacji wygaśnięcia stosunku pracy, „Studia Iuridica Lublinensia” 2015, vol. XXIV.

Stelina J., Prawo pracy, Warszawa 2018.

Szurgacz H., Prawo pracy. Zarys wykładu, Warszawa 2016.

Tomanek A., Stosunki pracy $w$ razie likwidacji $i$ upadłości pracodawcy, Warszawa 2012.

Walczak K., Komentarz do Kodeksu pracy, Beck Online 2016, https:// prima.uwb.edu.pl:2056/document-view.seam?documentId=mjxw62zo gi3damrug42dqoboobqxalruhezdcmzwgm4q, dostęp:12.12.2019 r.

Wąż P., Następstwa prawne śmierci strony stosunku pracy, „Monitor Prawniczy" 2008, nr 4.

Wichrowska-Janikowska E., Nawiązywanie i rozwiązywanie umów o pracę, Toruń 1996.

Zbucka M., Skutki prawne śmierci pracodawcy, Lex Online 2018, https:/ / sip.lex.pl/\# /monograph/369443062/6?keyword=zbucka\%20marta\&tocHit=1\&cm=SFIRST (dostęp: 12.12.2019 r.). 